水 文 · 水資源学 会誌

J. Japan Soc. Hydrol. \& Water Resour.

Vol. 16, No. 5(2003) pp. 518-526

\title{
安定同位体比分析を用いた豪州乾燥地域における 樹木の水源推定に関する研究
}

Water sources estimation of trees in an arid area of

Western Australia by stable isotope ratio analysis

\author{
小島紀徳 ${ }^{*} \cdot$ 池田裕弥 ${ }^{*} \cdot$ 加藤 茂 $^{*}$ (成蹊大学工学部応用化学科) \\ Toshinori KOJIMA $\cdot$ Yuya IKEDA $\cdot$ Shigeru KATO \\ Department of Applied Chemistry, Seikei University \\ 松本 岡川*‡ \\ Tsuyoshi MATSUMOTO \\ 濱野裕之 $*+\ddagger \ddagger$ \\ Hiroyuki HAMANO \\ (成蹊大学工学部応用化学科, 新エネルギー・産業技術総合開発機構) \\ Department of Applied Chemistry, Seikei University, NEDO \\ (成蹊大学工学部応用化学科, 科学技術振興事業団) \\ Department of Applied Chemistry, Seikei University, JST

\section{岡田直紀 ${ }^{* *} \cdot$ 坪山良夫 ${ }^{* *} \cdot$ 斉藤昌宏 $^{* *}$ (森林総合研究所) \\ Naoki OKADA $\cdot$ Yoshio TUBOYAMA $\cdot$ Masahiro SAITO \\ Forestry and Forest Products Research Institute}

\section{安部征雄 ${ }^{* *}$} \\ Ikuo $\mathrm{ABE}$

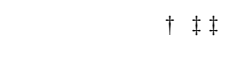 \\ Nobuhide TAKAHASHI \\ 山田興一 \\ Kouichi YAMADA

\section{(筑波大学農林工学系)} \\ Institute of Agricultural and Forest Engineering, University of Tsukuba \\ (信州大学繊維学部精密素材工学科, 科学技術振興事業団) \\ Department of Fine Materials Engineering, Shinshu University, JST \\ (信州大学繊維学部精密素材工学科) \\ Department of Fine Materials Engineering, Shinshu University
}

\footnotetext{
*成蹊大学工学部応用化学科 $\bar{\top}$ 180-8633 武蔵野市吉祥寺北町3-3-1

Department of Applied Chemistry, Seikei University , Kichijouji-kitamachi, Musashino, Tokyo, 180-8633, Japan.

† 新エネルギー・産業技術総合開発機構養成技術者

NEDO (New Energy and Industrial Technology Development Organization) , Fellow

**森林総合研究所研究員 $=305-8687$ 茨城県稲敷郡茎崎町松の里 1

Forestry and Forest Products Research Institute, Matsunosato, Kukizaki, Inashiki, Ibaragi, 305-8687, Japan

***筑波大学農林工学系 $=305-8572$ つくば市天王台1-1-1

Institute of Agricultural and Forest Engineering, University of Tsukuba, Tennodai, Tsukuba, Ibaragi, 305-8572, Japan.

†信州大学繊維学部精密素材工学科 T386-8567 上田市常田3-15-1

Department of Fine Materials Engineering, Shinshu University, Tsuneta, Ueda, Nagano, 386-8567, Japan.

ま科学技術振興事業団研究員

Postdoctoral fellow of Japan Science and Technology Corporation (JST), Fellow
} 
It is required to sequestrate $\mathrm{CO}_{2}$ for solving global warming problem. One of the measures proposed for $\mathrm{CO}_{2}$ sequestration is largescale afforestation in arid land. From this viewpoint, we set a demonstration/research area in Leonora, Western Australia (Abe et al., 1997; Matsumoto et al., 2000; Yamada et al., 1999). In the present study, the stable isotopes analyses $\left(\delta \mathrm{D}, \delta{ }^{18} \mathrm{O}\right)$ was conducted for roots and branches of natural tree species, and ground water and soil water in the specific arid area. It was estimated that the water source of Eucalyptus camaldulensis is ground water, and Acacia aneura and Hakea preissii, soil water. The time variation of the ratio through before to after a rainfall event was also measured for several tree species including those artificially planted under different conditions. It was found that the response of trees to the event has varieties depending on not only their species but also their environmental conditions. The present results show the possibilities of selection of tree species fitting for the actual water conditions and application of suitable water management technologies to a specific tree for the most efficient afforestation of arid areas.

Key words: Arid land, Afforestation, Stable isotope ratio analysis, Estimation of water sources

地球温暖化の最も重要な原因物質である $\mathrm{CO}_{2}$ の有効な削減策の提示が急がれている.近年, $\mathrm{CO}_{2}$ 削減策の1つとして, 乾燥地植 林による炭素固定が提案されており，西オーストラリア州レオノラ地域で実証試験がなされている (安部ら，1997；松本ら，2000； Yamada et al., 1999). 光こで本研究では, レオノラ地域に自生する主要樹種の枝，根中の水の安定同位体比分析 $\left(\delta \mathrm{D}, \delta{ }^{18} \mathrm{O}\right)$ を用 い, 地下水や表層土猿水の弚れと比較した .これから, Eucalyptus camaldulensis は地下水, Acacia aneura および Hakea preissii は表 層土壌水が主たる水源であることが推定された . 人工的に植林された樹木を含む，樣々な条件下で成育する種々の樹種について， 降雨の前後にかけて同樣な測定を行い, 樹木の水源の変化についても考察した . 弚の結果, 降雨に対する応答は, 樹種ばかりでは なく，樹木の環境条件によっても影響を受けることがわかった . 水条件に適した樹種を選択し，あるいは樹木に適した水条件を人 工的に作り上げることにより，限られた水を効率的に利用し，効率的な植林が可能となると期待される .

キーワード : 乾燥地, 植林, 安定同位体比分析, 水源推定

\section{I . 緒 言}

地球温暖化の最も重要な原因物質である二酸化炭 素の大気中濃度削減法の一つとして, 乾燥地におけ る大規模植林による炭素固定が提案されている . 対 象乾燥地としてさまざまな地域が考えられるが , 著 者らは西オーストラリア州レオノラ地域を研究調査 対象地として選択した(安部ら，1997)．レオノラ地 域は典型的な内陸性乾燥気候を示しており，年平均 降水量は約 $220 \mathrm{~mm} / \mathrm{y}$ と乏しい。また, 場所的, 季節 的にも降水パターンは不規則であり，これらを予測 することは非常に難しい．効率的な植林のためには， このわずかな降雨を有効に用いることが必要である が, まれに観測される大雨の際には大量の雨水が表 面流出し, 塩湖に至る.また, 表面流出しなかった 雨水についても，樹木に用いられることなく蒸発し てしまう量が多いと考えられる．

この地域における樣々な調査研究が, 著者らのグ ループにより実施されてきた .これまでに, 本地域 における植林による $\mathrm{CO}_{2}$ 固定量の定量的把握が行わ れてきた (Yamada et al., 1999) 。 また , $\mathrm{CO}_{2}$ 固定量と 土壤の透水性, 深度, 栄養塩濃度值との相関も報告 された (松本ら，2000）. 一方, 上述の無駄に流出， 蒸発している水を, 樹木に有効に供給する手段を提 案するためには, これらの樹種の水源を正確に推定
することが重要である．しかしながら，どの樹種が どのような水源を用いているのかについては, 未だ 明らかにされてこなかった .

水の由来を定量的に推定する方法として，安定同 位体比分析法が提案され, 分析法の改善 (吉田・水 谷, 1987)，樣々な因子の影響の考察 (池田, 1998; 町田 , 2000 ; Mizota and Kusakabe, 1994) もなされ てきた .さらに，樹木についても，植物体中の水を 抽出し, この分析結果と雨水の关れとの比較から, 雨期の推定を行った例 (Ehleringer, 1991; Silveira et al., 1987; Takahashi, 1998) に加え, 本研究と同樣に 樹木の水源を推定した論文 (Weltzin, 1997; Lisa et al., 1994; Peter et al., 1993) も報告されている . さら に，水源と植物の根の分布との関係についても報告 されている (Canadell, 1996; Dawson, 1996, 1998; Jackson et al., 1996) . しかしながら ，このような研 究を乾燥地に適用した例はみられない.これは, 対 象地が乾燥地である場合には, 現状では土地の経済 的価值が低く, 水文学的研究の必要性が乏しいとい う理由からだけではなく, 乾燥条件下でのサンプル 取得が難しいことも一因と考えられる．

上記の観点から, 本研究では, まず以下に詳細を 記載する実験 1 では, レオノラ地域に自然に生育す る数種の樹種について, 钅の水源の推定を試みた . フトモモ科ユーカリ属 E. (Eucalyptus) camaldulensis 
は現地で最も生育が早く，水条件がよい，すなわち 乾期でも根域に利用可能な水が存在すると考えられ るクリーク (水路 .ただし, 乾燥地では通常は枯れ ており，強降雨時のみ水が流れる) 沿いに生育する . この樹種は, 耐乾性, 耐塩性を持つといわれている (森ら，1996)。塩性土壤においては, 電気伝導度 $40 \mathrm{mS} / \mathrm{cm}$ ( =塩濃度約 $2 \%, 0.02 \mathrm{~g} / \mathrm{cm}^{3}$ ) まで生育可 能といわれている(森ら，1996)。耐乾性については， 降水量の少ない時期は, 地下水を水源としていると 推定している報告も見られ (Lisa, J. M. et al., 1994; Peter, J. T. et al., 1993) , 乾燥地においても根の成長 が早く, 水が得られる土壌深くまで, また広域に根 を伸ばすことができるためとも考えられる．

一方, 当該地域に最も広く分布するマメ科アカシ ア属 A. (Acacia) aneura は, 年降水量200 500 mm/y, 年間降雨日数30〜60日の地域に広く生育しており， 耐乾性を持った樹種である．ただし，耐塩性は有さ ないといわれている(森ら，1997）。

本研究では, これらの主要な 2 樹種に加え, これ らの樹種との比較という観点からヤマモガシ科ハッ ケア属 H. (Hakea) preissii も測定対象とした . H. preissii は，粘土層やローム層または砂丘によく見られ， 樹木ではあるが，成木樹高は最大 $2 \mathrm{~m}$ 程度である . A. aneura と性質が良く似ており, 耐乾性を持つ樹 種である .

また，現地で試験的に植林がなされている Site を 対象とした実験 2 では, 上記の代表 2 樹種に加え， 両者の中間的な成長速度を有するとされるモクマオ ウ科モクマオウ属 C. (Casuarina) obesa をも対象と した . C. obesaは，現地にはまれな樹種であるが， その耐乾性から, 試験植林での主要対象樹種として いるものである .

本測定により，地下水を主たる水源としている樹 種か確定されたならば, 以下の植林戦略が可能とな ろう.すなわち, 地下水脈が多く存在する地域であ れば表面流出水を，あるいは地表において蒸発する 水を積極的に地下水に導くことで, 水資源の有効活 用になると期待される。一方, 地下水脈が無い地域 への植林は, 表層土猿水を主として用いる樹種を用 いることとなろう.さらに，水を人工的に与える際 には，これらの樹種の主たる水源を特定した上で実 施することにより，節水が図れることとなる．

本研究においては, レオノラ地域に生育する樹木 数種中の水, ここに存在する代表的な井戶水, 土壤 水について安定同位体比分析 $\left(\delta \mathrm{D}, \delta{ }^{18} \mathrm{O}\right)$ を行い，
光の大規模な水源推定の検討を行った(実験 1 ) . 現 地が日本から離れていること, さらには上述のよう に乾燥地では降雨が得られることが非常にまれであ ることから，連続的な測定は困難であったが，現地 滞在中に降雨を得ることができ, また，炎の後の植 物中の安定同位体比変化に関するデータをも取得す ることができ(実験 2 ), 興味深い結果を得られたた め，ここで報告する．

\section{II . 調査地および研究方法}

\section{1 . 研究調査地の概要}

研究調査地は, 西オーストラリア州・レオノラ地 域の東西150km, 南北130km に広がるスタウト・メ ドウズに存在する . 自然状態での植生調査地 (Site (数字で表示), 灌水等の技術導入により植生改善 を試みた地域(Site は大文字英字で表示)および，付 近の井戶の位置 (×印) を Fig. 1 に示した 。

\section{2 . 研究方法}

1 ) 2000 年 8 月30日から 9 月 6 日までの現地調査 (実験 1 )

本調査では, 樹種および生育条件の違いによって，

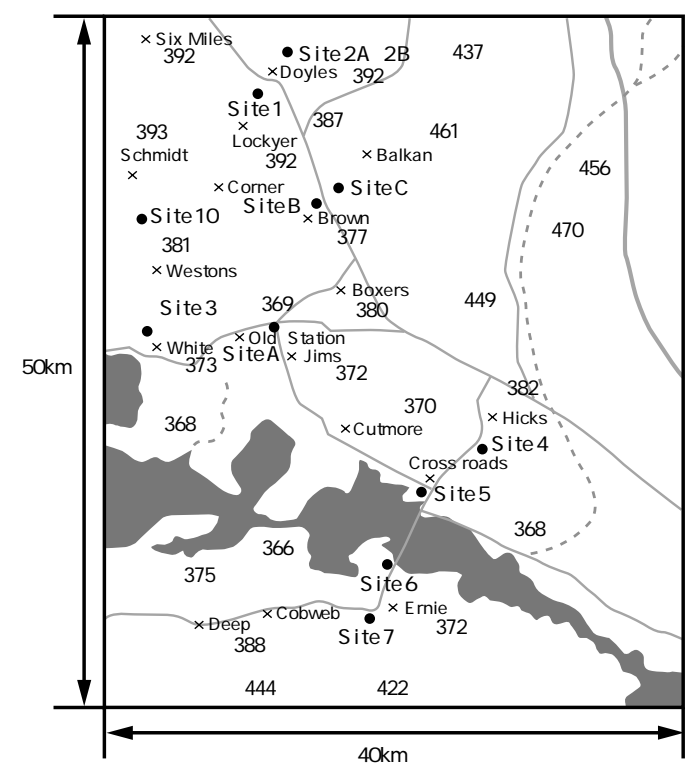

図 - 1 調査地域の詳細

Fig. 1 Detail of the research area 
樹木の水利用状況に与える影響が，どの程度である か測定した .

本研究で対象とした各 Site の特徵をまず示す. Site 1 はクリークの光ばに位置する Site であり，E. camaldulensis が主に群生している. Site $2 \mathrm{~A}$ は，A. aneura が数10m の範囲で群落をなして生育してい る地域である . Site 2B は, Site 2A の周囲に位置し , 一面草地となっており，一部土壌も露出している． Site 2A の中心から130m 離れた地点には ,H. preissii がまばらに生育している．また, Site 1 と Site 2 とは 位置的に近く，ほぼその中央に Doyles well (地表か ら水面までの深さ $3.1 \mathrm{~m})$ が存在する .

サンプル採取を行った時期は，2000年 8 月17日， 19日に乥れ光れ $4 \mathrm{~mm}$ の降雨があつた後の 8 月30日 から 9 月 6 日にかけてである . サンプル条件を以下 に示す。

樹木中の水の採取にあたっては, 枝及び根を対象 とした、枝は，採取する樹高や方角を変えた。各 Site で2 種類ずつ採取した . 根や土猿は採取する場 所の深さを変えた . 根は, Site 1では, 深さ 0 $140 \mathrm{~cm}$ で20cm 毎に 8 種, 160 200 cm で $40 \mathrm{~cm}$ 毎に 2 種採取した . Site $2 A, 2 B$ では光れ羿れ20〜 $50 \mathrm{~cm}$ ， 10〜30 cm で10cm 毎に 4 種, 3種を採取した . 土壤 は,Site 1 では, 0 100cm で20 cm 毎に 6 種 , 150〜 $200 \mathrm{~cm}$ で50 c m毎に 2 種採取した .

採取する際，枝に関しては，なるべく成熟した枝 (茶色い枝)を選択した . 成長過程にある枝は, 光合 成によって水が消費されることによる同位体比の変 化が懸念されるためである．また，根，土猿に関し ては，根か存在した深さに注意して採取している． 地下水は, 井戶からポリ瓶に直接採取した . 蒸発に よる同位体比の変化が無いように, 採取した全ての サンプルを冷凍保存した . 採取すると同時に樹木の 枝，根に関して観察を行なった .

Site 1 では樹高 $14 \mathrm{~m}$, 樹冠幅 $8.0 \mathrm{~m}$, 幹の周囲長 0.6mのE. camaldulensisの枝，根を採取した . 枝は北 西 $3.1 \mathrm{~m}$ ，南東 $2.8 \mathrm{~m}$ の方向の枝を採取した . 土壤を $2 \mathrm{~m}$ まで掘り, 最も根が多く分布していた深さは $60 \mathrm{~cm}$ であった . 根は, 水平方向にも鉛直方向にも分 布していた .これらのことから，表層土猿水と地下 水の両者を利用しているのではないかと推測される .

Site $2 \mathrm{~A}$ では, 樹高 $9.0 \mathrm{~m}$, 樹冠幅 $5.0 \mathrm{~m}$, 幹の周囲 長 $60 \mathrm{~cm}$ のA. aneura の枝, 根を採取した .土鋊を $50 \mathrm{~cm}$ まで掘り, 最も根が多く分布していた深さは $20 \mathrm{~cm}$ であることを確認した . また，根は水平方向
のみに分布していた .これらのことから , 主に降雨 後の表層土埣水を利用しているのではないかと推測 される .

Site 2Bでは，樹高約 1.5mのH. preissii の枝，根を 採取した.土壤は $1 \mathrm{~m}$ まで掘り, 最も根が多く分布 していた深さは20cm であることを確認した . また， 根は水平方向のみに分布していた .これらのことか ら，主に降雨後の表層土壤水を利用しているのでは ないかと推測される。

2 ) 2001年 9 月 5 日から 9 月15日までの現地調査 (実験 2 )

降雨後，樹木の利用している水の同位体比が，ど のように変化しているかを把握するため, 牧場拠点 (牧場内での唯一の人の居住地であり，宿舎もここ に併設) 内にあり，サンプルを採取しやすい Site A で,E. camaldulensis, C. obesa を対象として，各樹木 の枝を採取した . 尚 Site A は前述のように人工的植 林サイトであり，4.5m間隔で種々の樹種90本が植林 されており，成長に及ぼす灌水頻度の影響が調査さ れている.本サンプルを採取した極乾燥時には最頻 で半月程度の間隔で, 地下水を用いた灌水を行って いる. 調査日前後には 9 月 3 日に $40 \mathrm{~mm}$ に相当する 灌水を行っている .

また，人工的植林サイトである Site A に加えて， Site A 付近で自然状態にある樹木も測定対象とした . 降雨 $(4 \mathrm{~mm}$ ) があった 9 月 6 日の 1 日前 ( 5 日)，1 (7日)，4 (10日)，9日後 (15日) の各樹木の枝を 採取した。採取時間は, 朝, 夕刻あるいは夜である. 雨水は, 降雨を直接ポリ瓶に溜めて採取した。地下 水は宿舎での日常生活および灌水に用いている直近 の井戶 (Well Site A と記載) から採取した. 実験 1 と同樣に全てのサンプルを冷凍保存した .

\section{3 . 分析方法}

地下水, 雨水は炎のまま得られたものを試料とし た.土壤水については, 採取した土壤から, 高速冷 却遠心分離器 (佐久間製作所製 50A-IVD) を用い, $8^{\circ} \mathrm{C}, 8700 \mathrm{rpm}$ の条件 (pF2-4)で，2 時間かけて抽 出して得られた水を試料とした．枝や根については， 採取した試料を，万力を用いて圧搾することで水を 抽出した．このように得られた水をガス同位体比質 量分析計 (Finning 社, MAT252) で分析した。

なお，枝や根の試料については本邦への輸送の困 難さから，試料量を最低限に抑えたため，一部の試 料量の不足を招き, 十分な水量が得られず，精度あ 
る測定結果が得られなかったことがある．

\section{4. 安定同位体比分析}

水を構成する主要な安定同位体として，水素 $(\mathrm{H}$ に対する D)，酸素 $\left({ }^{16} \mathrm{O}\right.$ に対する $\left.{ }^{18} \mathrm{O}\right)$ に注目した 。 慣例に従い，安定同位体比分析結果を，次式で定義 されるঠ $\left(\delta \mathrm{D}, \delta{ }^{18} \mathrm{O}\right)$ 値で表した .

$$
\delta=\left(R_{\mathrm{SA}}-R_{\mathrm{ST}}\right) / R_{\mathrm{ST}} \quad[\% \text {, 千分率 }]
$$

ここで $R_{\mathrm{SA}}$ はサンプル中の, また $R_{\mathrm{ST}}$ は標準平均海 水 (SMOW) 中の, $\mathrm{D} / \mathrm{H}$ あるいは ${ }^{18} \mathrm{O} /{ }^{16} \mathrm{O}$ の存在量比 であり， $\delta$ 値は標準物質からの同位体存在量比の偏 差を表す . 地下水あるいは表層土鋊水と樹木水との $\delta$ 值の差が小さいほど, 樹木が先の水資源に水源を 依存していることを意味する .

\section{III . 結果及び考察}

\section{1. 実験 1}

\section{1 ) Site 1 (E. camaldulensis) の場合}

Fig. 2 に,Site 1 で採取したE. camaldulensisについ ての結果を, 表層土壤水(深さ $60 \mathrm{~cm}$ のみ, 十分な量 の水が抽出された，近辺の井戶水の分析結果と共 に示す . 結果については , 水素についての偏差を縦 軸に, 酸素を横軸に取った . 左あるいは下に行くほ ど， $\delta$ 值が小さいすなわち軽い水であることを示す． ここで根, 土猿についての数字は地表面からの深さ, 枝についての英字は方向を表す．

E. camaldulensisの枝，根のঠ 值には, 方向や深さ による大きな違いは見られず，また根と枝の違いも はっきりとは見られない.また，これらのర 值 $(\delta$ $\mathrm{D}=-46 \%{ }^{18} \mathrm{O}=-5.9 \%$ ）は，周辺地下水である Doyles well のঠ 值とほぼ一致していることがわか

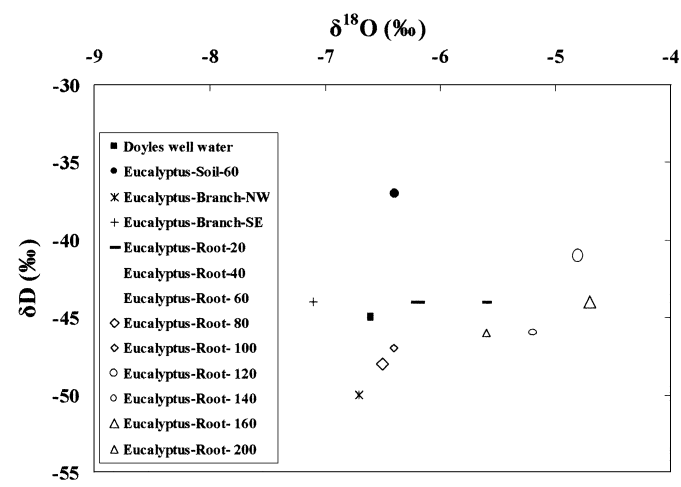

图 - 2 安定同位体比分析結果 (サイト 1)

Fig. 2 Result of stable isotope ratio analysis(Site 1)
る.一方，表層土壤水の結果とは異なった值を示し ている.これらの結果から，E. camaldulensis は，地 下水を主な水源としていると考えられる .

E. camaldulensis が生育している表層土壌中には， 他の Site で多く見られたハードパン (西豪州に広く 分布する不透水層. シリカを主成分とし, 鉄分, 力 ルシウムを含むことも多く，これらの作用により堆 積土壤が固化して形成されたとされている.)の存在 は認められず，地下水を水源としているとの上記の 推定とは矛盾しない．E. camaldulensis が生育する地 域は, 降雨が起こればクリークに水が流れ, 弚のク リーク沿いの深層に水が溜まる地域である . 通常， 耐乾性が高いといわれているE. camaldulensis では あるが, 降水量200mm 程度の本乾燥地域では, 光 の中でも水条件のよい地域でしか生育していないこ とから，この樹種の育成のためにはこのような水条 件で, さらには, 根が地下水脈に到達するまでに十 分な灌水などの手段を施すことが必要であると本研 究で推定される.

尚，本結果中では Doyles well の地下水の $\delta \mathrm{D}, \delta$ ${ }^{18} \mathrm{O}$ 值は表層土猿水よりも低い，すなわち，軽い水 であるとの結果を得ている . 降雨自身の同位体比に は季節変動があることから, 降雨後から長時間かけ て集積したと思われる地下水の同位体比が，比較的 直近に得られた雨水を反映する表層土猿水と大きく 異なることは不思議ではない．

さらに,一般的には, 表層土壤水は以下の理由に より地下水より重くなる傾向があるものと考えられ る.すなわち, 表層土猿水は, 表面から浸透した雨 水か蒸発することにより，雨水より重い可能性が高 い. また, 降雨開始直後の水が重い水であるとすれ ば, 乾燥土壤に降り始めた雨はまず蒸発するが , 次 いで乾燥土壌がこれを強い力で吸収する．一方，地 下に浸透する水は, 土畩が飽和状態になった後の比 較的軽い水であると考えれば, 地下水は雨水より軽 くなると考えることができる .

2 ) Site 2A (A. aneura), 2B (H. preissii) の場合 測定結果を Fig. 3 に示す . Site $2 \mathrm{~A}$ での表層土猿水 は, 深さ $20 \mathrm{~cm}$ 付近でのみ抽出することができた . Site $2 \mathrm{~B}$ では十分な量の水の抽出が出来なかった .

Site $2 \mathrm{~A}$ に成育するA. aneura については, E. camaldulensis と同樣に枝と根の同位体比には, 試料採 取深さによる大きな違いが見られないことがわかる . A. aneuraの枝 , 根のঠ Dは約 - 30\%。であり,${ }^{18} \mathrm{O}$ は約 $5.0 \%$ である .これらの值は, 表層土壌水の值と近 


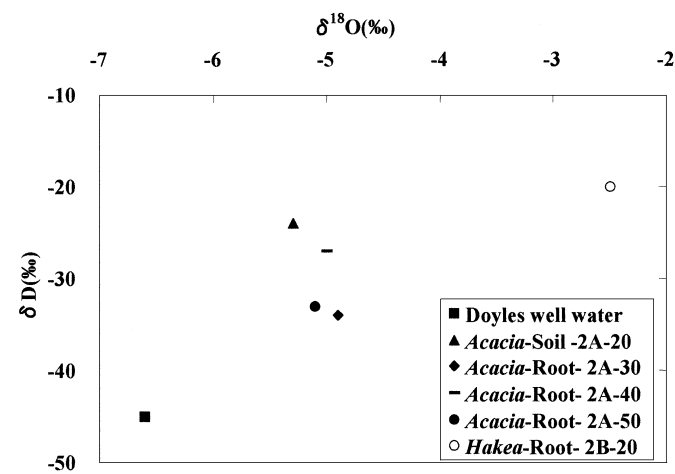

図－3 安定同位体比分析結果 (サイト 2 A , 2B )

Fig. 3 Result of stable isotope ratio analysis (Site 2A, 2B)

い値となっており，一方，地下水とは大きく異なっ ている.更には，この地域のハードパンまでの深さ は約40cm であり，このことからも主な水源が地下 水とは考えにくい，以上のことから，水源としては， 表層土壌水が最も主要なものとして考えられる .

Site 2B のH. preissii に関しては, Site 2A に成育す るA. aneura と同樣に, 水源が地下水とはいえない ばかりではなく，弚の植物中の水は A. aneuraより さらに重い水となっていた .これは, 降雨後に表層 に存在した水を主に利用していたか, あるいは表層

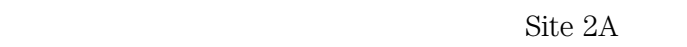
重い水となっていたと推定できる．なお，Site 2Bの 土壤の含水率は小さく, 水を抽出することが出来な かった .このことからも蒸発が進んでいたことが裏 づけられる. また Site $2 \mathrm{~A}$ の樹木密度は高く，表面 からの蒸発は Site 2B に比べ, 相当小さいものと考 えられる .

E. camaldulensis と A. aneura との結果を併せて Fig. 4 に示す. また, 弚れ光れの平均值も示した .

両者の平均值を比較すると, A. aneura は E. c c a maldulensis より，重い水を利用していたことがわか る.また, 土壌水についても, Site $2 \mathrm{~A}$ の值は Site 1 の值より重かった .これより, 蒸発の進み易い方か ら, Site 2B, Site 2A, Site 1 の順であったと考えられ る.また，地下水を吸水しているE. camaldulensis が樹高, 胸高直径のいずれについても最も大きく成 長し, 次に,A. aneuraが大きく,H. preissii は最も小 さい，すなわち，深いところから水を吸う樹種ほど 大きく成長するとの関係がみられた .

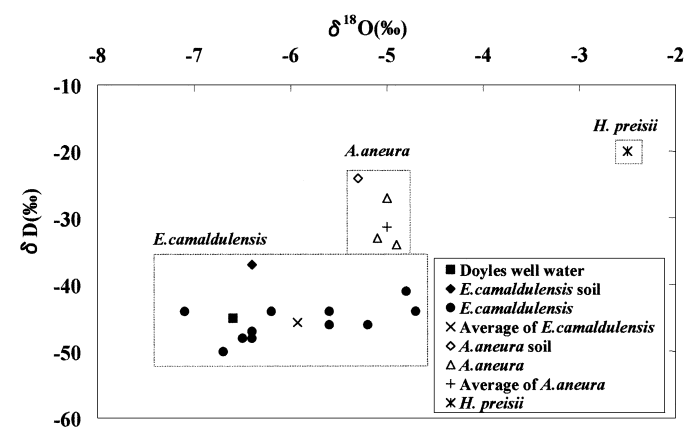

図 - 4 安定同位体比分析結果 (サイト1,2A，2 B )

Fig. 4 Result of stable isotope ratio analysis

\section{2 . 実験 2}

実験 2 で得られた結果を Fig. 5 および 6 に示す . Fig. 5 は自然に近い状況で成育している樹木のデー タであり，Fig. 6 は人工的に成育させた Site A の結 果である. 降雨水についての結果は両図に示したが，

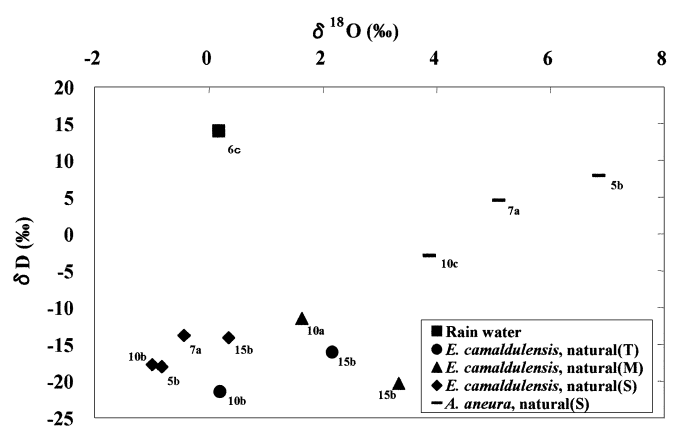

図 - 5 安定同位体比分析結果 (自然)

Fig. 5 Result of stable isotope ratio analysis (natural)

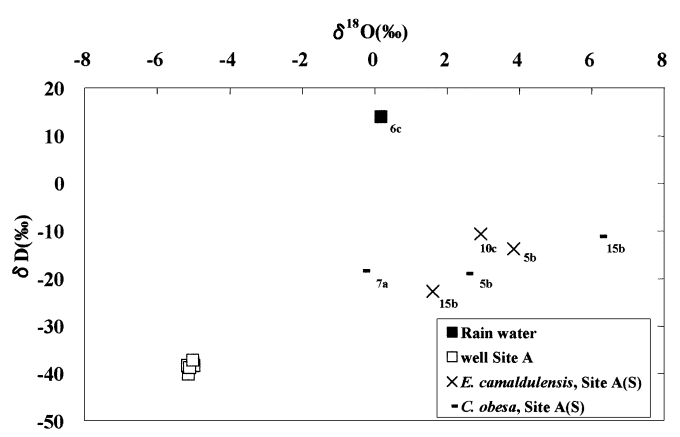

図 - 6 安定同位体比分析結果 (サイトA)

Fig. 6 Result of stable isotope ratio analysis (Site A) 
地下水の結果は作図の都合上, Fig. 5 のみに示して いる. 図中にある数字は, サンプルを採取した日付 を表している．また，採取時間として8〜9時をa， 17〜19時を b ，21〜23時を c と表記する．

自然に近い状況で成育している 3 本の $E . c a-$ maldulensis を区別するため, $\mathrm{T}$ (tall)は樹高約15m，M (medium) は約 $6 \mathrm{~m}, \mathrm{~S}$ (short) は約 $4 \mathrm{~m}$ ものとす る.他の樹木についても, 参考のため, 上記と同樣 な基準で, $\mathrm{T}, \mathrm{M}, \mathrm{S}$ と記載した. 尚, natural と記 載されている樹木の内で, E. camaldulensis-natural (S) およびA. aneura-natural $(\mathrm{S})$ は牧場拠点からも 離れており，完全に自然な状態で生育しているもの であるが, E. camaldulensis-natural (T) および (M) は, 牧場拠点にも近く恣意的ではないが付近にはス プリンクラーもあり, 地下水が若干灌水されている 可能性がある .

また，このときに得られた雨水は，実験 1 よりも さらに重い水であり，一方，地下水については，実 験 1 に比して若干重い。

まず，Fig. 5 中に示した自然に成育している樹木 に関するデータについて述べる．ほとんど全ての データが, 雨水を除き, 右上と左下とを結ぶ直線上 に存在している.雨水のみ, この直線からはずれ， 大きなঠDの值を示している. 雨水については , 採 取時間や採取場所による違いも原因の一つとして今 後検討する必要があるが , ここでは以下のように整 合性のある解釈が可能であった ${ }^{18} \mathrm{O}$ の值のみで考 察を行なう．また，他の一部のデータについても， 下記のように,$\delta \mathrm{D}$ の変化が ${ }^{18} \mathrm{O}$ と異なることにつ いて,さらに検討が必要である。

前述のように, 直前の灌水からは時間が経っては いるが，灌水用に用いた水も軽い地下水であり，一 方, 本実験 2 では土壤水の測定は行ってはいないも のの，実験 1 で示したように土壌水は，重い水であ ると考えられる.降雨直前 ( 5 日) の植物中の水は, 自然に成育するA. aneura のみについては重く, 表 層付近の水を使用している比率が高いと考えられる

一方, E. camaldulensisについては, 地下水より重 いが, A. aneura に比べれば軽く，一部表層土壤水を 用いているものの, 地下水あるいは篧溉水への依存 度が高い。

降雨後の変化を見ると,A. aneura については軽い 方向への変化か顕著に見られる.これは, 降雨前に は乾燥状態にあるA. aneura 中の水が重かったのに 対し, 降雨後には降雨水を大量に, かつ迅速に吸収

\section{したことによると推定される．}

また, 元々の樹木中の水が, 非常に重い水であっ たため, 以下の他の樹種に見られた表層土壌水の乾 燥による重い方向への変化が表れなかったものと考 えられる .

一方, 自然状態で灌水の影響を全く受けていない E. camaldulensis $(\mathrm{S})$ のঠ 值をみると, 降雨前は, 今 回測定した全ての樹種の内, 最も地下水に近い值を 示した．降雨後は若干重くなる傾向が見られ，雨水 のঠ值に近づいたものの, 降雨による変化は比較的 小さい．このことから，この樹高は $4 \mathrm{~m}$ ほどと低い にも関わらず，地下水が主たる水源であり，この程 度の降雨ではあまり大きな影響を受けていないこと がわかる.

牧場拠点近くにある樹高約 $15 \mathrm{~m}(\mathrm{~T})$ と樹高約 $6 \mathrm{~m}$ (M)のE. camaldulensis の水のঠ 值については，いず れも降雨前の測定は行っていないものの, 降雨後は 重くなる方向への変化が見られ, 降雨後の表層土壌 水をも吸い, かつ弚の後の乾燥の進行による変化を 表しているように思われる . しかしながら , 樹高 6 $\mathrm{m}$ のE. camaldulensis $(\mathrm{M})$ については, $\delta \mathrm{D}$ の変化 は $\delta^{18} \mathrm{O}$ と異なる方向性を示しており, さらに検討 が必要である。

次に, Fig. 6 に示した人工的植林 Site である Site A に成育しているE . camaldulensis と C. obesaにつ いてのデータについて述べる .

降雨前については, 同じE. camaldulensis であっ ても, Site A に植裁されている樹木中の水は, 自然 に育成している樹木に比べより重い．これは，表層 から灌水されている地下水が, 乾燥に伴って重くな り，木が觉の水を吸っていたためと考えられる．

さらに,Site A に育成するE. camaldulensis の降雨 前後の変化は, 自然状態にあるE. camaldulensis と は異なり, 变化の方向はむしろ自然に成育する $A$. aneuraに近い, 軽くなる方向が示された .これは, Site A では表層からの灌水によって水条件が改善さ れており, 根系が比較的表層にも発達し, 降雨にも 反応したためと考えられる.他の植林 Site ではある が , Site C でE. camaldulensis の根の発達状況を観察 し，実際に比較的太い根が下方および水平方向の両 者に伸びていることも確認した．また，土壌も，植 林の際に掘り起こしているため, 降雨水も土猿中に 浸透しやすかったと考えられる，一方，降雨後の乾 燥による重い方向への変化がみられなかった理由は， 現地の樣子を見ると表層が枯れ草などで覆われてお 
り，降水後の乾燥が進みにくかったためと考えられ る。

一方，同樣な水条件にある C. obesa については， 降雨前には E. camaldulensis に近い値を示していた が, 降雨後は $\delta \mathrm{D}$ の変化は小さいものの, $\delta^{18} \mathrm{O}$ は一 度軽い方向に動いた後, 大きく重い方向に変化した． この樹種は成長が比較的速く, 同樣に Site C での観 察によれば，根は E. camaldulensisに比して細く， 多数が全体に密に広がっていることが確認されてい る.このことから，降雨によりまず雨水に反応して 軽くなったが, 乾燥に伴い重い方向に移行したもの と考えられる。しかし, 降雨前には, この值より軽 い, 地下水に近い值であったことを考えると, 細か い根が状況に応じて水源を変えている可能性が示唆 されよう.

\section{IV . 結 言}

レオノラ地域に自生する主要樹種の枝, 根中の水

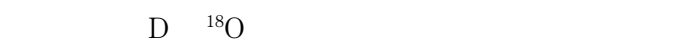
水の弚れと比較した。これから, 現地で水条件の良 い所に成育するE. camaldulensis は地下水, 現地で 最も広く見られるA. aneura, さらに乾燥条件下で 成育する H. preissii は表層土壤水が主たる水源であ ることが推定された .これらの結果は, 樹木の根分 布測定, ハードパンの有無の観察結果とも良い整合 性を示した。

また, 降雨前後について同位体比の変化を測定し た. E camaldulensis と A. aneuraの 2 樹種に加え, 人 工的に植林された Site では両者の中間的な成長速度 を有するとされる C. obesa をも選択して同樣な測定 を行ったところ, 結果は, 条件や樹種により異なる 挙動を示した。耐乾性を持ち, 表層土壌で水平方向 に根をよく伸ばす A. aneura は, 降雨に迅速に応答 した 、一方，自然状態にあり，鉛直方向の太い根を 有するE. camaldulensis は, 地下水を主たる水源と することから，降雨に対する応答はわずかであった . 一方，地下水を用いた灌水を行っているE. camaldulensis中の水は, 自然状態のE. camaldulensisに 比してもともと重く, また降雨後の応答もA. aneura に近い軽い方向に向かう応答が見られた . 灌水 を行なったことで, 表層付近にも根が発達していた と考えることが出来る.一方, 灌水を受けていた C. obesaについては, 降雨前は E. camaldulensis に近 い值であったが, 多方向に細かい根が発達している ことを反映し, 降雨に敏感にかつ変化の方向も大き
く変化し, 水条件により水源を変えている可能性が 示唆された .

水条件に適した樹種を選択し，あるいは樹木に適 した水条件を人工的に作り上げることにより，限ら れた水を効率的に利用し, 効率的な植林が可能とな ると期待される .

謝辞: 本研究は, 科学技術庁・戦略的基礎研究「乾 燥地植林による炭素固定システムの構築 (代表 山 田興一)」によって実施された .ここに記し，謝意を 表する .

\section{引用文献}

安部征雄 · 小島紀德・山田興一 (1997) : 二酸化炭 素対策としての乾燥地における大規模植林, 沙 漠研究, 7-1, pp. 77-81.

池田光良・高田 茂・松枝大治 (1998)：「北海道の 環境水中のトリチウム濃度および $\delta \mathrm{D} \delta{ }^{18} \mathrm{O}$ の高 度効果の推定值について」, Radioisotopes, 47, pp. 812-823.

町田 功 (2000) : 「東京都三宅島における降水の酸 素安定同位体時空間変化」, 13-2, pp. 103-11.

松本 剛 - 田中淑子 - 小島紀德 - 加藤 茂 · 斉藤昌 宏・安部征雄・山田興一 (2000) : 西オーストラ リア・レオノラ乾燥地域における $\mathrm{CO}_{2}$ 固定大規模 植林技術の検討(1) 塩と植生との関係, 日本海 水学会, $\mathbf{5 4 , p p . ~ 1 9 6 - 2 0 4 . ~}$

森 徳典(1996): 熱帯樹種の造林特性 第1巻 テ キストNO. 8, (財)国際緑化推進センター,pp. 200208.

森 徳典(1997)：熱帯樹種の造林特性 第 2 巻 テ キストNO. 9 ，財国際緑化推進センター,pp. 104118.

吉田尚弘・水谷義彦 (1987)：「水試料の酸素同位体 比測定の簡略化」, 21, pp. 83-90.

James, R. E., Susan, L. P., William, S. F. S., and Darren, R. S. (1991): Differential utilization of summer rains by desert plants, 88 , pp. 430-434.

J. Canadell, R. B. Jackson, J. R. Ehleringer, H. A. Mooney, O. E. Sala, E. D. Schulze (1996): Maximum rooting depth of vegetation types at the global scale, Oecologia, 108, pp. 583-595.

Leonel, S. L. S. and Peter K. S. (1987): Utilization of freshwater and ocean water by coastal plants of southern Florida, Ecology, 68-6, pp. 1898-1905. 
Lisa, J. M., Peter, J. T., Steve, D. T. and Glen, R. W. (1994):Sources of water used by riparian Eucalyptus camaldulensis overlying highly saline groundwater, Oecologia, 100, pp. 21-28.

Mizota, C. and Kusakabe, M (1994): Spatial distribution of $\delta \mathrm{D}, \delta^{18} \mathrm{O}$ values of surface and shallow ground waters from Japan, south Korea and east China, Geochemical Journal, 28: pp. 387-410.

Peter, J. T. and Glen, R. W.(1993): The Source of Water Transpired by Eucalyptus camaldulensis: Soil, Groundwater, or Stream? Stable Isotope and Plant Carbon-Water Relations, pp. 511-527.

R. B. Jackson, J. Canadell, J. R. Ehleringer, H. A. Mooney, O. E. Sala and E. D. Schulze (1996): A global analysis of root distributions for terrestrial biomes, Oecologia, 108, pp. 389-411.
Takahashi, K (1998): Oxygen isotope ratio between soil water and stem water of trees in pot experiments, Ecological Research, 13, pp. 1-5.

Todd, E. D. (1998): Fog in the California redwood forest: ecosystem inputs and use by plants, Oecologia, 117: pp. 476-485.

Todd, E. D. and John, S. P. (1996): Seasonal water uptake and movement in root systems of Australia phraeatophytic of dimorphic root morphology: a stable isotope investigation, Oecologia, 107, pp. 1320 .

Yamada, K., Kojima, T., Abe, Y., Williams, A. and Law, J. (1999): Carbon Sequestration in an Arid Environment Near Leonora, Western Australia. J. Arid Land Studies, 9-2, pp. 143-151.

(受付 : 2002年 8 月 8 日, 受理 : 2003年 2 月22日) 